\title{
The absence of the financial investigation in the Slovak Republic and its consequences
}

\author{
Lucia Kurilovská*, Marek Kordík**
}

\begin{abstract}
* JUDr. Lucia Kurilovská PhD., associate professor at the Department of the Criminal Law, Criminology and Criminalistics of the Faculty of Law, Comenius University in Bratislava; Rector of the Police Academy in Bratislava, Counsel to the Minister of Justice of the Slovak Republic; Senior Researcher of the Institute of the State and Law, Slovak Academy of Sciences. (e-mail: lucia.kurilovska@minv.sk)** Capt. JUDr. Marek Kordík PhD., LL.M., assistant professor at the Department of the Criminal Law, Criminology and Criminalistics of the Faculty of Law, Comenius University in Bratislava; Vice-Rector of the Police Academy in Bratislava. (e-mail: marek.kordik@flaw.uniba.sk) Abstract: According to current status financial investigation is not established by the Criminal Procedural Code or other legal source in a formal way in Slovakia. The study analyses this situation de lege lata and de lege ferenda.
\end{abstract}

Keywords: financial crimes; financial investigation; forfeiture of property

\section{Introduction}

Pursuant to Criminal Procedural Code, 1 assets from criminal activities are subject to evidence to the extent of their income, range, content, and height. From the perspective of the investigative process performed by the judicial and police authorities, the gathering of illegal assets as evidence deriving from criminal activities is required, and treated as any other subject of evidence as it relates to mens rea or actus reus.

The primary reason why it is necessary to investigate illegal assets from criminal activities is to create a sufficient procedural base for judicial impositions of the sanctions related to the confiscation of income from criminal activities.

Section 58(2) of the Criminal Code $\underline{2}$ stipulates the first category of crimes punishable by the confiscation of property, while taking into account the circumstances under which the criminal offence was committed, and the personal situation of the offender. The court may order the forfeiture of property of the offender whom it sentences to life imprisonment or to unconditional imprisonment for a particularly serious felony, through which the offender gained or tried to gain large-scale property benefits or caused large-scale damage. The large scale benefit or damage is defined pursuant the Section 125(1) of the Criminal Code as a sum at least equal to $133,000 €$. 
The second category when the court orders the forfeiture of property, even in the absence of the conditions referred above when sentencing perpetrators of criminal offences for so-called predicative offences, 3 is if the offender has acquired a substantial extent of property, or part thereof from the proceeds of crime. Substantial extent or damage is defined pursuant to Section 125(1) of the Criminal Code as a sum at least equal to $26,600 €$.

The third category when the court mandates the forfeiture of property, even in the absence of the conditions referred above, when sentencing perpetrators for the criminal offence of the legalization of proceeds of crime pursuant to Section 233 of the Criminal Code when his or her property or part thereof was acquired from the proceeds of crime, at least in the substantial extent pursuant to Section 233(2), or acquired his or her property or part thereof from the proceeds of crime to at least a large scale extent. 4

\section{Current status}

Despite the legal obligation of the police and judicial authorities to gather evidence regarding illegal income from criminal activities and the mandatory obligation to impose the punishment of the forfeiture of property, statistics show conflicting data. Since 2011 there have been raised indictments in 111 cases, but no punishments have been imposed for the forfeiture of property, although individuals have been found guilty for the legalization of proceeds of crime pursuant to Section 233 of the Criminal Code.

While analyzing these cases, it is evident that the judicial ruling on the legal criteria for imposing the punishment of the forfeiture of property has not been met in these particular cases. The ruling may have been interpreted in a way that the judicial file has not included any or sufficient evidence to rule the forfeiture of the property. There should be a direct nexus proven between proceeds or assets and the particular criminal activity. Intent of the perpetrator to gather the proceeds or assets is insufficient for imposing the forfeiture of property.5. The process of gathering the evidence of the proceeds of crimes is subjected to financial investigation.

Financial investigation is a proceeding of the police and judicial authorities that is independent from the investigation and the prosecution for the predicative crime. Financial investigation is a secondary and supplementary evidence gathering process focused on the trace and undercover of the proceeds from the criminal activities in order to establish reasonable ground to impose 
the punishment of the forfeiture of property by the judicial authority, or to decide to freeze assets in the pre- trial or trial phase to ensure the proper execution of further judicial decision if the legitimate criteria are met.

Currently, the financial investigation has not been established by the Criminal Procedural Code, nor by any other relevant legal source, at least in a formal way. Additionally, financial investigations have not been incorporated into the organizational structures of police forces nor the prosecutor's offices. It is important to note that the police or judicial authority performing an investigation are currently completely allocated for the investigation of the predicative crimes, and they time time and/or personal capacity to perform a financial investigation.

\section{Table n. 1. Seizure of assets in Slovakia done by the Financial Intelligence Unit of the National Criminal Agency $\underline{6}$}

\begin{tabular}{|l|l|}
\hline Y2011 & 40 \\
\hline Seizure of money acc. S. 95 of the Criminal Procedural Code & 1 \\
\hline Seizure of security papers acc. S. 96 of the Slovak Criminal Code & 7 \\
\hline $\begin{array}{l}\text { Surrender of items acc. S. } 550 \text { of the Criminal Procedural Code (evidence in the judicial } \\
\text { cooperation in the criminal matters) }\end{array}$ & 2 \\
\hline $\begin{array}{l}\text { Seizure of property acc S. } 551 \text { of the Criminal Procedural Code (the execution of the foreign asset } \\
\text { related judicial decision in the judicial cooperation in the criminal matters) }\end{array}$ & \\
\hline
\end{tabular}

Table n. 2. Criminal offence of money laundering acc. Section 233 of the Criminal Code

\section{in the area of the district prosecutor's offices?}

\begin{tabular}{|l|l|}
\hline Y2011 & 19 \\
\hline Prosecution & $17 / 0$ \\
\hline Indictment/Plea bargaining & $\begin{array}{l}\text { Imprisonment-7 } \\
\text { Confiscation of property-O }\end{array}$ \\
\hline Sentenced &
\end{tabular}


Table n. 3. Seizure of assets in Slovakia done by the Financial Intelligence Unit of the National Criminal Agency $\underline{8}$

\begin{tabular}{|l|l|l|}
\hline Y2012 & $\begin{array}{l}\text { Criminal offence of money } \\
\text { laundering acc. S. 233 and S. } \\
234 \text { of the Criminal Code }\end{array}$ & $\begin{array}{l}\text { Other } \\
\text { criminal } \\
\text { offences }\end{array}$ \\
\hline Seizure of money acc. S. 95 of the Criminal Procedural Code & 40 & 45 \\
\hline $\begin{array}{l}\text { Seizure of security papers acc. S. } 96 \text { of the Slovak Criminal } \\
\text { Code }\end{array}$ & 1 & 5 \\
\hline $\begin{array}{l}\text { Surrender of items acc. S. } 550 \text { of the Criminal Procedural } \\
\text { Code (evidence in the judicial cooperation in the criminal } \\
\text { matters) }\end{array}$ & 7 & 0 \\
\hline $\begin{array}{l}\text { Seizure of property acc. S. } 551 \text { of the Criminal Procedural } \\
\text { Code (the execution of the foreign asset related judicial } \\
\text { decision in the judicial cooperation in the criminal matters) }\end{array}$ & 2 & 0 \\
\hline
\end{tabular}

\section{Table n. 4. Criminal offence of money laundering acc. Section 233 of the Criminal Code in the area of the district prosecutors' offices?}

\begin{tabular}{|l|l|}
\hline Y2012 & 47 \\
\hline Prosecution & $34 / 6$ \\
\hline Indictment/Plea bargaining & $\begin{array}{l}\text { Imprisonment-8 } \\
\text { Confiscation of property-0 }\end{array}$ \\
\hline Sentenced &
\end{tabular}

Table n. 5. Seizure of assets in Slovakia done by the Financial Intelligence Unit of the National Criminal Agency 10

\begin{tabular}{|l|l|l|}
\hline Y2013 & $\begin{array}{l}\text { Criminal offence of money } \\
\text { laundering acc. S. 233 and S. } \\
234 \text { of the Criminal Code }\end{array}$ & $\begin{array}{l}\text { Other } \\
\text { criminal } \\
\text { offences }\end{array}$ \\
\hline Seizure of money acc. S. 95 of the Criminal Procedural Code & 12 & 0 \\
\hline Seizure of security papers acc. S. 96 of the Slovak Criminal & 0 & 1
\end{tabular}




\begin{tabular}{|l|l|l|} 
Code & & \\
\hline $\begin{array}{l}\text { Surrender of items acc. S. } 550 \text { of the Criminal Procedural } \\
\text { Code (evidence in the judicial cooperation in the criminal } \\
\text { matters) }\end{array}$ & 0 & 42 \\
\hline $\begin{array}{l}\text { Seizure of property acc. S. } 551 \text { of the Criminal Procedural } \\
\text { Code (the execution of the foreign asset related judicial } \\
\text { decision in the judicial cooperation in the criminal matters) }\end{array}$ & 0 & 48 \\
\hline
\end{tabular}

Table n. 6. Criminal offence of money laundering acc. Section 233 of the Criminal Code in the area of the district prosecutors' offices 11

\begin{tabular}{|l|l|}
\hline Y2013 & 46 \\
\hline Prosecution & $24 / 8$ \\
\hline Indictment/plea bargaining & $\begin{array}{l}\text { Imprisonment-21 } \\
\text { Confscation of property-0 }\end{array}$ \\
\hline Sentencing & \\
\hline
\end{tabular}

Table n. 7. Criminal offence of money laundering acc. Section 233 of the Criminal Code in the jurisdiction of the Special Prosecutor's Office 12

\begin{tabular}{|l|l|}
\hline Y2013 & 11 \\
\hline Prosecution & 10 \\
\hline Indictment/Plea bargaining & $\begin{array}{l}\text { Imprisonment-0 } \\
\text { Confiscation of property-0 }\end{array}$ \\
\hline Sentencing &
\end{tabular}

Table n. 8. Seizure of assets in Slovakia done by the Financial Intelligence Unit of the National Criminal Agency 13 .

\begin{tabular}{|l|l|l|}
\hline Y2014 & $\begin{array}{l}\text { Criminal offence of money } \\
\text { laundering acc. S. 233 and S. } \\
234 \text { of the Criminal Code }\end{array}$ & $\begin{array}{l}\text { Other } \\
\text { criminal } \\
\text { offences }\end{array}$ \\
\hline Seizure of money acc. S. 95 of the Criminal Procedural Code & 22 & 198
\end{tabular}




\begin{tabular}{|l|l|l|}
\hline $\begin{array}{l}\text { Seizure of security papers acc. S. } 96 \text { of the Slovak Criminal } \\
\text { Code }\end{array}$ & 0 & 1 \\
\hline $\begin{array}{l}\text { Surrender of items acc. S. } 550 \text { of the Criminal Procedural } \\
\text { Code (evidence in the judicial cooperation in the criminal } \\
\text { matters) }\end{array}$ & 2 & 37 \\
\hline $\begin{array}{l}\text { Seizure of property acc. S. } 551 \text { of the Criminal Procedural } \\
\text { Code (the execution of the foreign asset related judicial } \\
\text { decision in the judicial cooperation in the criminal matters) }\end{array}$ & 7 & 24 \\
\hline
\end{tabular}

\section{Table n. 9. Criminal offence of money laundering acc. Section 233 of the Criminal Code in the area of the district prosecutors' offices 14}

\begin{tabular}{|l|l|}
\hline Y2014 & 48 \\
\hline Prosecution & $31 / 4$ \\
\hline Indictment/Plea bargaining & $\begin{array}{l}\text { Imprisonment-12 } \\
\text { Confiscation of the property- } 0\end{array}$ \\
\hline Sentencing & \\
\hline
\end{tabular}

Table n. 10. Criminal offence of money laundering acc. Section 233 of the Criminal Code in the jurisdiction of the Special Prosecutor's Office 15.

\begin{tabular}{|l|l|}
\hline Y2014 & 12 \\
\hline Prosecution & $7 / 3$ \\
\hline Indictment/Plea bargaining & $\begin{array}{l}\text { Imprisonment-3 } \\
\text { Confiscation of property- } O\end{array}$ \\
\hline Sentencing &
\end{tabular}

We have provided the statistics regarding the legalization of proceeds of crime pursuant to Section 233 of the Criminal Code. The statement given above is in regards to the effectiveness of prosecution and the sanctioning of economic crimes as such.

A comprehensive financial investigation is considered one of the most effective tools to fight against organized crime. Seizing and sourcing out the income of organized crime works preventively, as it is able to stop generating 
additional income by these groups. In this way it narrows the possibilities for serious criminal activities. 16

\section{The necessity of effective financial investigation}

Verification and tracing of financial transactions, digital data in account or CRM17 systems, or other databases may identify any illegal income, payments, secret accounts, non-justifiable items and entries in ledgers, and/or illegitimate depreciations. Financial investigations have led to the discovery of hidden SPVs, $\underline{18}$ acting in accordance with business relations or transaction schemes including information on real beneficiary owners.

The urgent need to identify any person who exercises ownership or control over a legal entity in order to ensure effective transparency has been articulated in the basic anti-money laundering legal source within the EU: the recently adopted IV. Directive. 'Identification and verification of beneficial owners should, where relevant, extend to legal entities that own other legal entities, and obliged entities should look for the natural person(s) who ultimately exercises control through ownership or through other means of the legal entity that is the customer. Control through other means may, inter alia, include the criteria of control used for the purpose of preparing consolidated financial statements, such as through a shareholders' agreement, the exercise of dominant influence or the power to appoint senior management. There may be cases where no natural person is identifiable who ultimately owns or exerts control over a legal entity. In such exceptional cases, obliged entities, having exhausted all other means of identification, and provided there are no grounds for suspicion, may consider the senior managing official(s) to be the beneficial owner(s).'12 'The need for accurate and up-to-date information on the beneficial owner is a key factor in tracing criminals who might otherwise hide their identity behind a corporate structure. Member States should therefore ensure that entities incorporated within their territory in accordance with national law obtain and hold adequate, accurate and current information on their beneficial ownership, in addition to basic information such as the company name and address and proof of incorporation and legal ownership. 20 Member States should ensure that the widest possible range of legal entities incorporated or created by any other mechanism in their territory is covered. While finding a specified percentage shareholding or ownership 
interest does not automatically result in finding the beneficial owner, it should be one evidential factor among others to be taken into account. Member States should be able, however, to decide that a lower percentage may be an indication of ownership or control. 21

Linking true beneficiary owners and their assets with the committed crimes are key factors of a successful financial investigation. Tracing these links is usually known as a creation of an economic profile or asset profile of the accused. Economic profiling is a part of a financial investigation, and is usually based upon open source checks. The gathered evidence should not be used only for investigation and prosecution of money laundering, but as important evidence in the prosecution for the predicative crime (e.g. to provide a more complete picture of the structure of an organized group).

Another reason to support effective financial investigations in the Slovak Republic are detailed in the following recommendations of Money Val experts, which stipulate that: - the Slovak authorities could give more specific training on money laundering and terrorist financing offences, and the seizure, freezing, and confiscation of property that is the proceeds of crime, or is to be used to finance terrorism, to police, prosecutors, and judges; 22 and - an increase in dedicated resources and staff to the FIU for its activities in the supervision field, and for its performance of a more effective national coordination role. 23

The experts also emphasized that:

- more training on terrorist financing-related issues, including those regarding the implementation of SR III requirements, should be provided to the National Bank of Slovakia's supervisory staff involved in Anti-Money Laundering / Combating the Financing of Terrorism (AML/CFT) initiative; 24

- authorities should provide the FIU with additional resources to allow more detailed coordination on the national level; 25 .

- there are some deficits on the effectiveness of money laundering and terrorist financing investigations; $\underline{26}$

- there is currently a lack of sufficient coordination between major players of the AML/CFT regime;27-

- more effective mechanisms are needed to coordinate at the operational level; $\underline{28}$ and - there is no evidence of concrete arrangements for coordination of seizure and confiscation actions with other countries, or for sharing confiscated assets with them, other than those provided under the Framework Decision applicable for EU Member States.29? 


\section{Conclusion}

Legal development in the Slovak Republic has grown significantly in recent years while continuously evolving and adopting new tools to make the fight against economic crime more effective. A new Whistleblowing Act,30 allows Parliament to address the act of criminal responsibility of legal persons. It is possible that all these legislative activities may become obsolete, and the Slovak Republic will fulfill the expected criteria only in a formal way. The current system of investigation and prosecution does not rely on the financial investigation, and the staff will not be able to put these (both recently adopted and still developing) legal tools into practice. The justification for the failure to do so will likely be that the 'practitioners have not got used to' the process, as evidenced in the statistics. Another such tool is the called in-direct criminal responsibility of legal persons, established through the sanction-protective measure of the forfeiture of money sum or forfeiture of property. It was been established in 2011, and since then, no claim against a legal person has been raised, and no legal person has been brought before the court.

\section{References}

1. Act no.141/1961 (Code of Criminal Procedure).

2. Act no. 300/2005 (Criminal Code).

3. Illicit manufacturing and possession of narcotics or psychotropic substances, poisons or precursors, and trafficking in them pursuant to Section 172 paragraphs 2, 3 or 4, or Section 173, criminal offence of trafficking in human beings pursuant to Section 179, criminal offence of trafficking in children pursuant to Section 180 paragraphs 2 or 3 or Section 181, criminal offence of extortion pursuant to Section 189 paragraph 2 (c), criminal offence of gross coercion pursuant to Section 190 paragraphs 1, 3, 4 or 5 , or Section 191 paragraphs 3 or 4, criminal offence of coercion pursuant to Section 192 paragraphs 3 or 4, criminal offence of sharing pursuant to Section 231 paragraphs 2, 3 or 4, or Section 232 paragraphs 3 or 4, criminal offence of legalization of proceeds of crime pursuant to Section 233 or 234, criminal offence of forgery, fraudulent alteration and illicit manufacturing of money and securities pursuant to Section 270, criminal offence of uttering 
counterfeit, fraudulently altered and illicitly manufactured money and securities pursuant to Section 271 paragraph 1, criminal offence of manufacturing and possession of instruments for counterfeiting and forgery pursuant to Section 272 paragraph 2, criminal offence of failure to pay tax and insurance pursuant to Section 277, criminal offence of failure to pay tax pursuant to Section 278 paragraphs 2 or 3 , criminal offence of breach of regulations governing state technical measures for labelling goods pursuant to Section 279 paragraphs 2 or 3, criminal offence of establishing, masterminding and supporting a criminal group pursuant to Section 296, establishing, masterminding and supporting a terrorist group pursuant to Section 297, criminal offence of terror pursuant to Section 313 or Section 314 , criminal offence of accepting a bribe pursuant to Section 328 paragraph 2 or 3, or Section 329 paragraphs 2 or 3, criminal offence of bribery pursuant to Section 334 paragraph 2 or Section 335 paragraph 2, criminal offence of counterfeiting and altering a public instrument, official seal, official seal-off, official emblem and official mark pursuant to Section 352 paragraph 6, criminal offence of smuggling of migrants pursuant to Section 355 or Section 356, criminal offence of procuring and soliciting prostitution pursuant to Section 367 paragraph 3, criminal offence of manufacturing of child pornography pursuant to Section 368, criminal offence of dissemination of child pornography pursuant to Section 369, criminal offence of corrupting morals pursuant to Section 372 paragraphs 2 or 3 , or criminal offence of terrorism and some forms of participation on terrorism pursuant to Section 419

4. For the purposes of this article we have decided to illustrate the current status of the financial investigation in the Slovak republic at the statistics of the criminal offense of the legalization of proceeds of crime pursuant to Section 233 with the data analyses back to 2011, when the last Money Val evaluation took place. Evaluation report of the Slovak republic by the Money Val,

http://www.coe.int/t/dghl/monitoring/moneyval/Evaluations/round $4 / S V K 4$ MER MONEYVAL\%282011\%2921 en.pdf (accessed 21 September 2015) 5. Wouter H. Muller, Christian H. Kälin, John G. Goldsworth (eds.), Anti-money laundering-International law and practice, 12 (Chichester, John Wiley \& Sons Ltd, 2007). 
6. FIU Annual report 2011, translated by the authors, http://www.minv.sk/swift data/source/policia/naka opr/fsj/Vyrocna sprava \%20SJEP\%202011.pdf (accessed 15 September 2015) 7. Annual statistics of the criminal and non-criminal agenda in 2011, Office of the Prosecutor General, translated by the authors, http://www.genpro.gov.sk/statistiky= $\underline{12 c 1 . h t m l}$ (accessed 15 September 2015) ‥ FIU Annual report 2012, supra n. 6

9. Annual statistics of the criminal and non-criminal agenda in 2012, Office of the Prosecutor General, Translated by the authors, http://www.genpro.gov.sk/statistiky-12c1.html (accessed 15 September 2015) 10. FIU Annual report 2012, supra n. 6

11. Annual statistics of the criminal and non-criminal agenda in 2013, Office of the Prosecutor General, Translated by the authors, http://www.genpro.gov.sk/statistiky-12c1.html (accessed 15 September 2015) 12. Annual statistics of the criminal and non-criminal agenda in 2013, Office of the Prosecutor General, Ibid.

13. FIU Annual report 2014, http://www.minv.sk/swift data/source/policia/naka opr/fsj/Vyrocna sprava \%20SJFP\%202011.pdf (accessed 15 September 2015) 14. Annual statistics of the criminal and non-criminal agenda in 2014, Office of the Prosecutor General, Translated by the authors, http://www.genpro.gov.sk/statistiky= 12c1.html (accessed 15 September 2015) 15. Annual statistics of the criminal and non-criminal agenda in 2014, Office of the Prosecutor General, Ibid.

16. Wouter H. Muller, Christian H. Kälin, John G. Goldsworth (eds.), Antimoney laundering-International law and practice, 22 (Chichester, John Wiley \& Sons Ltd, 2007).

17. Customer management systems a.g. Oracle, SAP, SAS.

18. Special purpose vehicle- in this context a legal entity established for a single purpose mainly for the 'tax optimization', corruptive practices or money laundering.

19. Point 13 of the Preamble to the Directive (EU) 2015/849 of the European Parliament and of the Council of 20 May 2015 on the prevention 
of the use of the financial system for the purposes of money laundering or terrorist financing, amending Regulation (EU) No 648/2012 of the European Parliament and of the Council, and repealing Directive 2005/60/EC of the European Parliament and of the Council and Commission Directive 2006/70/EC, http://eur-lex.europa.eu/legalcontent/EN/TXT/HTML/?uri= CELEX:32015L0849\&from=EN (accessed 15 September 2015) 20. Point 14 of the Preamble to the Directive (EU) 2015/849, Ibid.

21. Point 12 of the Preamble to the Directive (EU) 2015/849, Ibid.

22. Section 914, Compliance with the Recommendation n. 30 FATF, 4 Evaluation report of the Slovak republic by the Money Val, http://www.coe.int/t/dghl/monitoring/moneyval/Evaluations/round $4 / S V K 4$ MER MONEYVAL\%282011\%2921 en.pdf (accessed 21 September 2015) 23. Section 915, Compliance with the Recommendation n. 30 FATF, Ibid. The evaluators commented that the Slovak authorities should satisfy themselves that there are adequate resources allocated to set up and maintain the Anti-money laundering/Combating the financing the terrorism system on the policy level and that policy makers are appropriately skilled and provided with relevant training.

24. Section 918, Compliance with the Recommendation n. 30 FATF, Ibid. Section 919, Compliance with the Recommendation n. 30 FATF, Ibid.

25. Point 27, Table 1, Section 915, Compliance with the Recommendation n. 30 FATF, Ibid.

26. Point 27, Section 915, Compliance with the Recommendation n. 30 FATF, Ibid.

27. Point 31, Section 915, Compliance with the Recommendation n. 30 FATF, Ibid.

28. Point 31, Section 915, Compliance with the Recommendation n. 30 FATF, Ibid. The same has been pointed in Point 14 of the Preamble to the Directive (EU) 2015/849 of the European Parliament and of the Council of 20 May 2015 saying that more detailed and comprehensive statistics should be maintained with regard to the investigation and prosecution of ML and $\mathrm{TF}$, as well as on the provisional measures applied and confiscation of 
proceeds of all predicate offences. All these statistics should be analyzed on a regular basis to determine areas where more resources are required and to assess the effectiveness of the system.

29. Act no. 307/2014 (Whistleblowing Act) 